\title{
Effect of plant extracts on growth performance and insulin-like growth factor 1 secretion in growing pigs
}

\author{
Subramaniam Mohana Devi' ${ }^{1}$ Jae Won Park ${ }^{1}$, In Ho Kim ${ }^{1}$
}

${ }^{1}$ Dankook University, Department of Animal Resource and Science, Cheonan, Chungnam, South Korea.

\begin{abstract}
The objective of the present study is to evaluate the effects of plant extracts on growth performance, nutrient digestibility, and immune blood characteristics in growing pigs. A total of 80 [(Landrace $\times$ Yorkshire $) \times$ Duroc] pigs with an initial body weight $(\mathrm{BW})$ of $27.31 \pm 2.15 \mathrm{~kg}$ were used in a 6-wk experiment. Pigs were allotted to one of four treatments (1 - Control (CON) (basal diet); 2 - PE1 (CON + 0.05\% plant extracts); 3 - PE2 (CON + 0.10\% plant extracts); and 4 - PE3 $(\mathrm{CON}+0.15 \%$ plant extracts $))$ in a randomized complete block design according to sex and initial BW. The PE1 and PE2 treatments provided a greater average daily gain than the CON treatment. From weeks 0 to 6 the pigs fed diets PE2 and PE3 showed greater apparent total tract digestibility of dry matter than those fed the CON diet. Pigs fed the plant-extract treatments had a reduction in total mercaptan emission on day 3 compared with control treatment. On day 5, fecal acetic acid content was decreased with increased blood WBC (white blood cells) and lymphocyte counts and serum IGF-1 concentration by plant extract supplementation compared with the control treatment. All the results showed a $95 \%$ significance level. Supplementation of plant extracts can improve growth performance and nutrient digestibility in growing pigs, decrease fecal gas emission, and increase immune components such as WBC and lymphocytes, and serum IGF-1 concentration in growing pigs.
\end{abstract}

Key Words: IGF-1, plant extract

\section{Introduction}

The insulin-like growth factor I (IGF-1) is secreted by the liver and stimulated by GH, which in turn facilitates cartilage ossification and growth promotion (Suzuki et al., 2004). Owens et al. (1999) reported that plasma IGF-1 was positively associated with growth rate and feed efficiency in pigs. It was suggested that IGF-1 promotes lean tissue growth, whereas circulating IGF-1 is originated from the liver. The muscle and fat may act via endocrine mechanisms to stimulate lean tissue growth or may reflect somatic tissue production of IGF-1, which in turn acts as a paracrine growth factor. IGF-1 is used as a physiological criterion for genetic animal improvement, as the IGF-1 concentration increases steadily during animal growth, in contrast to the large circadian variation of GH (Scanes et al., 1987). IGF-1 is an essential growth factor for cell growth and development (Liu and LeRoith, 1999).

Four plant extracts of Phlomis umbrosa Turcz, Cynanchum wilfordii Hemsley, Zingiber officinale Rosc, and Platycodi Radix were specifically selected from

Received April 27, 2015 and accepted June 16, 2015.

Corresponding author: inhokim@dankook.ac.kr

http://dx.doi.org/10.1590/S1806-92902015001000003

Copyright (C) 2015 Sociedade Brasileira de Zootecnia. This is an Open Access article distributed under the terms of the Creative Commons Attribution License (http://creativecommons.org/licenses/by/4.0/), which permits unrestricted use, distribution, and reproduction in any medium, provided the original work is properly cited. natural pharmaceutical herbs that promote the secretion of IGF-1 (Kim, 2006). Choi et al. (2002) and Kim et al. (2002) reported that these plant extracts are very effective promoters of IGF-1 secretion, in experiments on humans and rats. A clinical test evaluating the effects of plant extracts on humans revealed that serum IGF-1 concentration showed a statistically significant increase in the groups treated with plant extract. Liu et al. (2008) reported that herbal extract supplementation led to an increase in average daily gain (ADG), serum IGF-1 level, and IGF-1 receptor mRNA in the tissue (stomach, duodenum, muscle) of pigs.

The enhanced growth performance and tissue-specific regulation of the IGF-1R mRNA level is due to suggestive herbal extract supplementation and controls IGF system in animals. Therefore, the objective of this study was to evaluate the effects of plant extracts on the IGF-1 on growth performance, nutrient digestibility, and blood immune characteristics of growing pigs.

\section{Material and Methods}

The experimental protocols describing the management and care of animals was reviewed and approved by the Animal Care and Use Committee of Dankook University, South Korea.

The plant extracts were processed with hot water at a temperature ranging from 60 to $95^{\circ} \mathrm{C}$. Extraction at lower temperatures yields a product that poorly induces secretion 
of IGF-1, while extraction at temperatures exceeding $95{ }^{\circ} \mathrm{C}$ is harsh and can destroy or disrupt the extraction of molecules. The crude extract was cooled, the precipitates were removed by centrifugation, and the components were separated on the basis of molecular weight, to obtain the desired extract containing the active ingredients with relatively low molecular weight (Kim, 2006).

A total of 80 [(Landrace $\times$ Yorkshire $) \times$ Duroc $]$ pigs with an initial body weight (BW) of $27.31 \pm 2.15 \mathrm{~kg}$ were used in a 6-wk experiment. Pigs aged 70 days were allotted to one of four treatments in a randomized complete block design according to sex and initial BW. There were four replicate pens per treatment, with five pigs per pen, in a total of 16 pens. The dietary treatments $(1-\mathrm{CON}$ (basal diet) (Table 1); 2 - PE1 (CON $+0.05 \%$ plant extracts); 3 - PE2 (CON $+0.10 \%$ plant extracts); and 4 - PE3 (CON $+0.15 \%$ plant extracts)) were formulated to meet or exceed the nutrient requirements recommended by NRC (1998). The plant extracts included the extracts from Phlomis umbrosa Turcz, Cynanchum wilfordii Hemsley, Zingiber officinale Rosc, and Platycodi Radix. Pigs were housed in an environmentally controlled nursery facility with slatted plastic flooring and a mechanical ventilation system. Each pen was equipped with a one-sided self-feeder and a nipple drinker to allow the pigs ad libitum access to feed and water throughout the experimental period.

The individual pig weight was measured at the beginning and end of the 6-wk experimental period by recording feed

Table 1 - Basal diet composition (as-fed basis)

\begin{tabular}{|c|c|}
\hline Ingredient (g/kg) & Basal diet \\
\hline Ground maize & 674.5 \\
\hline Soybean meal & 181.4 \\
\hline Rice bran & 50.0 \\
\hline Molasses & 50.0 \\
\hline Animal fat & 20.0 \\
\hline Defluorinated phosphate & 11.2 \\
\hline Calcium carbonate & 6.8 \\
\hline L-lysine $\cdot \mathrm{HCL}$ & 2.0 \\
\hline Salt & 1.5 \\
\hline Vitamin premix ${ }^{1}$ & 0.5 \\
\hline Mineral premix ${ }^{2}$ & 1.5 \\
\hline Choline chloride & 0.4 \\
\hline L-threonine & 0.2 \\
\hline \multicolumn{2}{|l|}{ Chemical composition $^{3}$} \\
\hline Digestible energy (MJ/kg) & 14.1 \\
\hline Crude protein $(\mathrm{g} / \mathrm{kg})$ & 148.0 \\
\hline Lysine $(\mathrm{g} / \mathrm{kg})$ & 8.9 \\
\hline $\mathrm{Ca}(\mathrm{g} / \mathrm{kg})$ & 7.4 \\
\hline$P(g / k g)$ & 5.4 \\
\hline \multicolumn{2}{|c|}{$\begin{array}{l}{ }^{1} \text { Provided per kg of complete diet: vitamin A - 4,000 IU; vitamin D3 - } 800 \mathrm{IU} \text {; } \\
\text { vitamin E - } 17 \mathrm{IU} \text {; vitamin } \mathrm{K}-2 \mathrm{mg} \text {; vitamin B2 - } 4 \mathrm{mg} \text {; vitamin B6 - } 1 \mathrm{mg} \text {; vitamin } \\
\text { B12 - } 16 \mu \mathrm{g} \text {; pantothenic acid - } 11 \mathrm{mg} \text {; niacin - } 20 \mathrm{mg} \text {; biotin - } 0.02 \mathrm{mg} \text {. } \\
{ }^{2} \text { Provided per kg of complete diet: Cu - } 220 \mathrm{mg} \text {; Fe - } 175 \mathrm{mg} \text {; } \mathrm{Zn}-191 \mathrm{mg} \text {; Mn - } 89 \mathrm{mg} \text {; } \\
\text { I - } 0.3 \mathrm{mg} \text {; Co - } 0.5 \mathrm{mg} \text {; Se - } 0.15 \mathrm{mg} \text {. }\end{array}$} \\
\hline
\end{tabular}

intake and the gain/feed ratio on a pen basis for analyzing ADG. The backfat thickness of the pigs was measured over the shoulder (first rib), on the midback (last rib), and on the rump (last lumbar vertebra) using a real-time ultra sound instrument (Piglog 105, SFK Technology, Herlev, Denmark). For the analysis of the fecal $\mathrm{NH}_{3}, \mathrm{H}_{2} \mathrm{~S}$, total mercaptan, and acetic acid, fresh feces were collected from two pigs in each pen on the last two days of the experiment. The total sampled feces were thawed and homogenized, before use. The feces were placed in 2.6-L plastic boxes with a small hole in the middle of one side that was sealed with adhesive plaster. The samples were allowed to ferment for one day at room temperature $\left(25^{\circ} \mathrm{C}\right)$, after which $100 \mathrm{~mL}$ of the headspace air was sampled from approximately $2.0 \mathrm{~cm}$ above the fecal sample. The concentrations of $\mathrm{NH}_{3}, \mathrm{H}_{2} \mathrm{~S}$, mercaptan, and acetic acid were measured within the scope of 5.0-100.0 ppm (No.3La, detector tube; Gastec Corp. Kanagawa, Japan) and 2.0-20.0 ppm (4LK, detector tube; Gastec Corp.). After collection, the boxes were re-sealed with adhesive plaster to measure the fecal noxious content at days 3 and 5 as aforementioned. Prior to measurement, the fecal samples were manually shaken for approximately $30 \mathrm{~s}$ to disrupt any crust formation on the surface of the fecal sample, and homogenized.

Chromium oxide $\left(\mathrm{Cr}_{2} \mathrm{O}_{3}\right)$ was added to the diet as an indigestible marker at $0.20 \%$ seven days prior to fecal collection at the 6th wk for calculation of dry matter (DM) and nitrogen $(\mathrm{N})$ digestibility. Fecal grab samples were collected at random from at least two pigs in each pen at the 6th wk of the experiment. All feed and feces samples were stored immediately at $-20{ }^{\circ} \mathrm{C}$ until analysis. Fecal samples were dried at $70{ }^{\circ} \mathrm{C}$ for $72 \mathrm{~h}$ and finely ground to pass through a $1-\mathrm{mm}$ screen. The procedures utilized for the determination of DM and $\mathrm{N}$ digestibility were conducted in accordance with the methods established by the AOAC (2000). Chromium levels were determined via UV absorption spectrophotometry (UV-1201, Shimadzu, Kyoto, Japan) and the apparent total digestibility (ATTD) of DM and $\mathrm{N}$ were calculated using indirect methods.

At the end of the experimentation period, two pigs were randomly chosen from each pen and blood samples taken by jugular venipuncture were collected in vacuum tubes (Becton Dickinson Vacutainer Systems, Franklin Lakes, NJ). White blood cells (WBC), red blood cells (RBC) and lymphocytes were determined using an automatic blood analyzer (ADVIA 120, Bayer, USA). For the analysis of serum biochemistry characteristics, samples were centrifuged at $3,000 \mathrm{rpm}$ at $4{ }^{\circ} \mathrm{C}$ for $15 \mathrm{~min}$ and the serum was separated. One half of the blood samples was subsequently centrifuged at 3,000 $\mathrm{g}$ for 15 min at $4{ }^{\circ} \mathrm{C}$, and the plasma was harvested. Thereafter, 
the samples were frozen and stored at $-20{ }^{\circ} \mathrm{C}$ until further analysis. Concentrations of IGF-1 were evaluated using commercially available ELISA kits (USCNK, China) and analyzed using a Microplate reader (Versmax, Molecular device, USA).

In the current study, all data were subjected to statistical analysis in a randomized complete block design using the GLM procedures of SAS (Statistical Analysis System, version 9.2), with the pen serving as the experimental unit and the initial $\mathrm{BW}$ used as a covariate for average daily feed intake (ADFI) and ADG. Duncan's multiple range test was used to compare the means of the treatments. Variability in the data was expressed as the pooled standard error ( $\mathrm{SE}$ ) and $\mathrm{P}<0.05$ was considered to be statistically significant.

\section{Results}

The PE1 and PE2 treatments showed higher ADG $(\mathrm{P}<0.05)$ than the $\mathrm{CON}$ treatment (Table 2). However, there were no significant differences observed in ADFI or Gain/Feed $(\mathrm{P}>0.05)$. At the end of the 6-wk period, the backfat thickness showed no significant difference $(\mathrm{P}>0.05)$ between the treatments.

During the 0 to 6 weeks of experiment, the pigs fed the $\mathrm{PE} 3$ diet showed greater $\mathrm{DM}$ digestibility $(\mathrm{P}<0.05)$ than those fed the CON diet (Table 3). The pigs fed the PE2 diet had a higher $\mathrm{N}$ digestibility than those fed the CON treatment $(\mathrm{P}<0.05)$. However, there was no significantly different result observed for energy digestibility. Pigs fed the plant extract showed a decrease $(\mathrm{P}<0.05)$ in the total mercaptan emission, by the third day, compared with those receiving the control treatment (Table 4). On day 5, acetic acid was decreased in the plant extract-supplemented diets, compared with the control treatment $(\mathrm{P}<0.05)$. The $\mathrm{NH}_{3}$ gas emission was found to have been decreased $(\mathrm{P}<0.05)$ on day 7 and no difference was observed in $\mathrm{H}_{2} \mathrm{~S}$ gas emission.

Supplementation with plant extract showed significant results in $\mathrm{WBC}$ and lymphocytes, when compared with the CON treatment $(\mathrm{P}<0.05)$, with no differences observed in RBC profile. However, the serum IGF-1 concentration was significantly different in the treatment with plant extracts compared with the control treatment $(\mathrm{P}<0.05)$. Among the treatments with plant extracts, PE3 showed a significantly higher numerical value compared with the other groups (Table 5). The IGF-1 level in the animals of the control group was $150.1 \mathrm{ng} / \mathrm{mL}$.

\section{Discussion}

Liu et al. (2008) reported that supplementation with herbal extract increased average daily gain, serum IGF-1 level, muscle IGF-1 mRNA, and muscle IGF-1 receptor mRNA in pigs. Ra et al. (2003) reported that the plant extracts-administered group showed higher $(49.3 \%$ and $52.3 \%$ ) growth promotion than the control group (46.2\%), by the increase in the GH and IGF-1 levels in rats. Antidiarrheal herbs can improve growth performance and prevent diarrhea in pigs (Cho et al., 2012).

Table 2 - Effect of plant extracts on growth performance of growing pigs

\begin{tabular}{|c|c|c|c|c|c|c|}
\hline Item & $\mathrm{CON}$ & PE1 & PE2 & PE3 & SE & P-value \\
\hline \multicolumn{7}{|l|}{0 to $6 \mathrm{wk}$} \\
\hline Average daily gain $(\mathrm{g})$ & $646 \mathrm{~b}$ & $683 a$ & $678 \mathrm{a}$ & $662 \mathrm{ab}$ & 10 & 0.016 \\
\hline Average daily feed intake ( $g$ ) & 1,523 & 1,575 & 1,599 & 1,567 & 27 & 0.102 \\
\hline Gain/feed & 0.424 & 0.434 & 0.424 & 0.422 & 0.006 & 0.081 \\
\hline \multicolumn{7}{|l|}{ Backfat thickness (6 wk) (mm) } \\
\hline Fore & 10.2 & 10.6 & 10.6 & 10.4 & 0.2 & 0.132 \\
\hline Middle & 8.6 & 8.7 & 8.6 & 8.7 & 0.2 & 0.090 \\
\hline Back & 10.2 & 10.4 & 9.8 & 10.0 & 0.3 & 1.000 \\
\hline Average & 9.7 & 9.9 & 9.7 & 9.7 & 0.2 & 1.000 \\
\hline
\end{tabular}

CON - basal diet; PE1 - CON $+0.05 \%$ plant extracts; PE $2-\mathrm{CON}+0.1 \%$ plant extracts; $\mathrm{PE} 3-\mathrm{CON}+0.15 \%$ plant extracts

$\mathrm{SE}$ - standard error.

$\mathrm{a}, \mathrm{b}-$ means in the same row with followed by different letters differ $(\mathrm{P}<0.05)$.

Table 3 - Effects of plant extracts on nutrient digestibility in growing pigs

\begin{tabular}{lcccccc}
\hline Item $(\%)$ & CON & PE1 & PE2 & PE3 & SE & P-value \\
\hline Dry matter & $76.89 \mathrm{~b}$ & $77.22 \mathrm{ab}$ & $77.48 \mathrm{ab}$ & $78.03 \mathrm{a}$ & 0.31 & 0.023 \\
$\mathrm{~N}$ & $75.40 \mathrm{~b}$ & $75.95 \mathrm{ab}$ & $76.63 \mathrm{a}$ & $75.61 \mathrm{ab}$ & 0.38 & 0.041 \\
Energy & 75.48 & 76.21 & 75.68 & 75.19 & 0.41 & 0.120 \\
\hline
\end{tabular}

CON - basal diet; PE1 - CON $+0.05 \%$ plant extracts; PE 2 - CON $+0.1 \%$ plant extracts; $\mathrm{PE} 3-\mathrm{CON}+0.15 \%$ plant extracts

$\mathrm{SE}$ - standard error.

$\mathrm{a}, \mathrm{b}$ - means in the same row with followed by different letters $\operatorname{differ}(\mathrm{P}<0.05)$. 
Table 4 - Effects of plant extracts on fecal gas emission in growing pigs

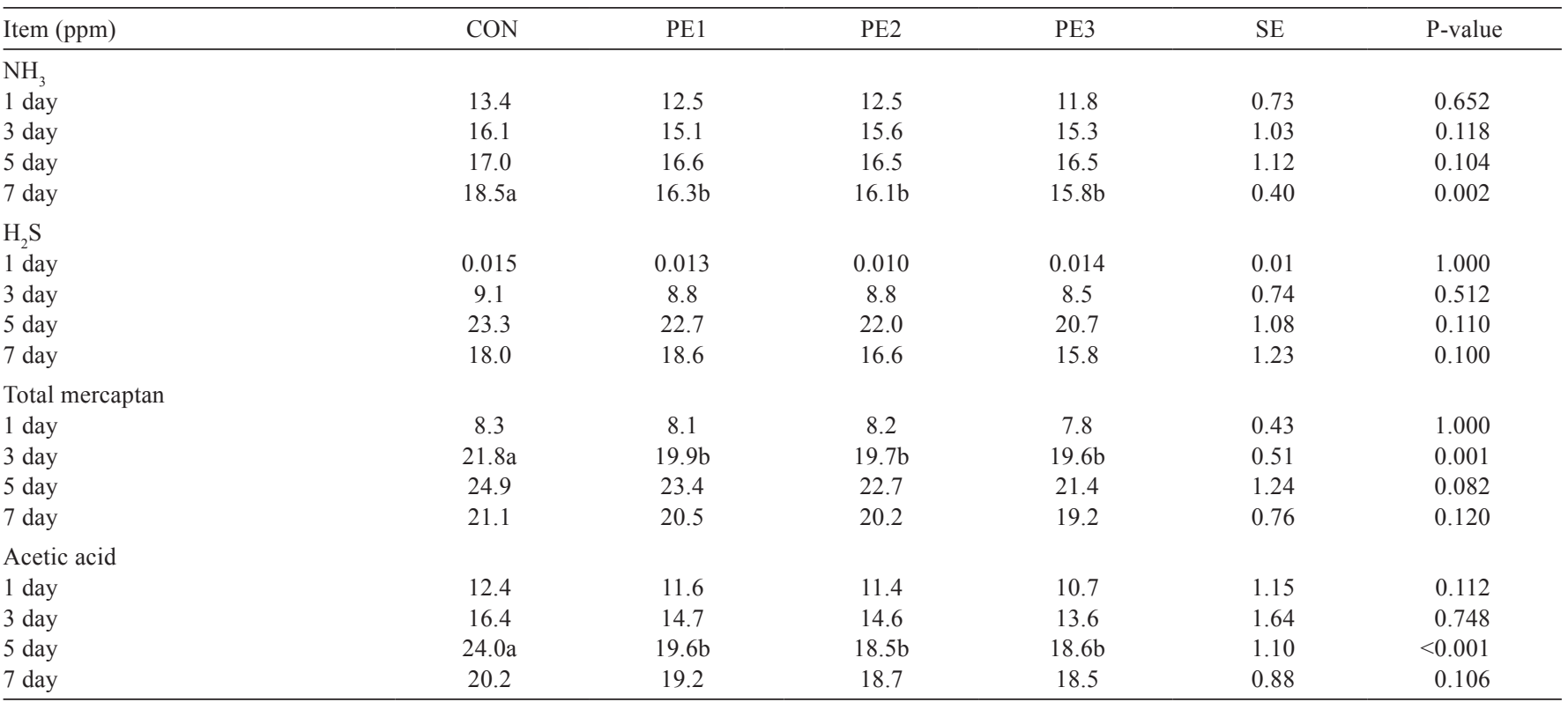

CON - basal diet; PE1 - CON $+0.05 \%$ plant extracts; PE 2 - CON $+0.1 \%$ plant extracts; PE $3-\mathrm{CON}+0.15 \%$ plant extracts

$\mathrm{SE}$ - standard error.

$\mathrm{a}, \mathrm{b}$ - means in the same row with followed by different letters differ $(\mathrm{P}<0.05)$.

Table 5 - Effects of plant extracts on blood characteristics of growing pigs

\begin{tabular}{|c|c|c|c|c|c|c|}
\hline Item & $\mathrm{CON}$ & PE1 & PE2 & PE3 & SE & P-value \\
\hline \multicolumn{7}{|l|}{$6 \mathrm{wk}$} \\
\hline IGF-1 (ng/mL) & $150.1 \mathrm{c}$ & $193.6 \mathrm{~b}$ & $200.4 b$ & $220.6 \mathrm{a}$ & 5.29 & 0.007 \\
\hline $\operatorname{RBC}\left(10^{6} / \mathrm{mL}\right)$ & 6.12 & 6.77 & 6.85 & 6.98 & 0.45 & 0.321 \\
\hline Lymphocytes (\%) & $61.0 \mathrm{~b}$ & $67.1 \mathrm{a}$ & $72.4 \mathrm{a}$ & $70.9 a$ & 2.03 & 0.014 \\
\hline
\end{tabular}

CON - basal diet; PE1 - CON $+0.05 \%$ plant extracts; PE2 - CON $+0.1 \%$ plant extracts; PE3 - CON $+0.15 \%$ plant extracts

$\mathrm{SE}$ - standard error.

$\mathrm{a}, \mathrm{b}$ - means in the same row with followed by different letters differ $(\mathrm{P}<0.05)$.

Klindt et al. (1998) reported that the injected pigs showed greater BW gain than those on the control treatment, and backfat deposition rate was not influenced by the administration of IGF-1. Greater concentrations of IGF-1 were observed in pigs with $90 \mathrm{~kg} \mathrm{BW}$ from a line selected for rapid growth, compared with the pigs from a line selected for slow growth (Lamberson et al., 1995). Owens et al. (1994) suggested that circulating IGF-1 serves as a reporter of growth performance, rather than a mediator of growth performance. Circulating IGF-1 concentrations were significantly correlated with the body size in three types of swine, which differed in growth rate and mature body weight, suggesting that IGF-1 is involved with the in vivo regulation of swine growth (Buonomo et al., 1987). However, Cameron et al. (2003) reported that serum IGF-1 was useful to predict ADFI physiologically, but not ADG and backfat depth, at six weeks of age. Studies demonstrated the relationships between plasma IGF-1 and growth performances, showing positive and negative correlation of plasma IGF-1 concentration at $25 \mathrm{~kg} \mathrm{BW}$, with estimated lean percentage at $90 \mathrm{~kg}$. On the other hand, the IGF-1 concentration at $60 \mathrm{~kg}$ was positively correlated with ADG, in Landrace and Yorkshire female pigs, although the IGF-1 concentration was correlated with ADG at approximately $75 \mathrm{~kg}$ of BW in finishing barrows (Lee et al., 2002; 2005). Eigenmann et al. (1984) studied the relationship between IGF-1 and GH, in which the circulating IGF-1 levels and body size were found to be highly significant, and body weight was correlated with IGF-1 levels rather than with the GH secretory capacity. In this study, supplementation of plant extracts increased the growth performance with an increase in IGF-1.

Oral administration of IGF-1 to unsuckled neonatal pigs increased small intestinal weight, protein and DNA content, and jejunal and ileal villus height, which means that oral infusion of IGF-1 increases the intestinal mucosal growth in pigs (Burrin et al., 1996). The plasma IGF-1 level was increased to the maximum, approximately $12 \mathrm{~h}$ after feeding, and plasma IGF-1 was probably considered to have an effect of energy balance under an abnormal 
temperature in pigs (Morovat et al., 1994). In a study on sepsis rats, IGF-1 improved the gut mucosal weight in the duodenum, jejunum, ileum, and colon (Chen et al., 1995). According to Lemmey et al. (1994), administration of IGF-1 improved gastrointestinal absorptive function by partial gut resection, which most likely reflects an increase in the gut absorptive surface area. In this study, the levels of IGF-1 increased with the addition of plant extracts, which is considered a positive factor that enhances gastrointestinal activities, thus decreasing the fecal gases. It is known that $\mathrm{NH}_{3}$ and $\mathrm{H}_{2} \mathrm{~S}$ are the main gaseous components of pig manure (Zahn et al., 1997). Cho et al. (2006) and Huang et al. (2010) suggested that extract of dietary herbs could reduce the fecal noxious gas content in pig manure. One reason for the reduction might be the increase in nutrient digestibility (Yan et al., 2010). In the present study, DM and $\mathrm{N}$ digestibility was increased by the supplementation of plant extracts, with a reduced $\mathrm{NH}_{3}$ gas emission, indicating that the plant extract could develop the digestive organ, increase nutrient digestibility, and decrease fecal gas emission. According to Yan et al. (2011b), dietary Houttuynia cordata and Taraxacum officinale extracts can increase growth performance, digestibility, and WBC concentration in finishing pigs. Administration of Saururus chinensis extract improves the serum lipid protein profile and decreases the emission of noxious gases in finishing pigs (Ao et al., 2011).

In in vivo models using mice, IGF-1 stimulates erythroid colony formation, and is the first defined mitogen that stimulates the late stages of erythroid differentiation (Kurtz et al., 1982). With the presence of erythropoietin (RBC-controlling hormone) in the culture, physiological concentrations of IGF-1 $(0.5-1 \mathrm{ng} / \mathrm{mL})$ stimulated erythroid cell growth and differentiation from bone marrow or peripheral blood (Claustres et al., 1987). Supplementation of herbs increases growth performance, lymphocyte count, $\mathrm{RBC}$, and WBC concentrations, and decreases the fecal noxious gas content in growing pigs (Yan et al., 2011a) and weaning pigs (Yan et al., 2012). Zhou et al. (2013) reported that dietary supplementation of the herb extract Coptis chinensis could increase blood erythrocytes in growing-finishing pigs. IGF-1 is a growth factor for the immune system that increases the total lymphocyte number and the number of $\mathrm{CD} 4+8+\mathrm{T}$ cells in thymus and spleen in rats (Hinton et al., 1997). IGF-1 was infused into mice to evaluate its effects on bone marrow B lymphopoiesis, and resulted in a significant increase in the total number of bone marrow B lineage cells and splenic B cells, 2 wk posttreatment (Stuart et al., 1991). Addition of plant extracts may be beneficial due to the increase in WBC, lymphocyte, and IgG levels, which in turn increases immunity. Also, the administration of plant extracts may induce positive effects on animals at early stages of their development. Kim et al. (2002) reported that the plant extracts-treated group showed an increase in serum IGF-1 concentration from 245.6 to $275.6 \mathrm{ng} / \mathrm{mL}$, in two months. Also, Choi et al. (2002) reported that the concentration of IGF-1 in blood was $1,140 \mathrm{ng} / \mathrm{mL} 8 \mathrm{~h}$ after the oral administration of plant extracts. Therefore, the present study postulates that plant extract supplementation may have increased the immune function by increasing IGF-1 and various actions of immunity. The IGF-1 level in the animals of the control group was $150.1 \mathrm{ng} / \mathrm{mL}$.

\section{Conclusions}

Plant extract supplementation can improve the growth performance and nutrient digestibility of growing pigs. Thus, the inclusion of plant extract has a positive impact on nutrient digestibility and stimulates intestinal enzyme activities. Plant extract treatments reduce fecal gas emission and increase immune components such as white blood cells and lymphocyte. Also, serum IGF-1 concentration is increased by the supplementation of plant extracts.

\section{References}

Ao, X.; Yan L., Meng, Q. W.; Zhou, T. X.; Wang, J. P.; Kim, H. J.; Cho, J. H. and Kim, I. H. 2011. Effects of Saururus chinensis extract supplementation on growth performance, meat quality and slurry noxious gas emission in finishing pigs. Livestock Science 138:187-192.

AOAC - Association of Official Analytical Chemists. 2000. Official methods of analysis. 17th ed. Association of Official Analysis Chemistry, Gaithersburg, MD.

Buonomo, F. C.; Lauterio, T. J.; Baile, C. A. and Campion, D. R. 1987. Determination of insulin-like growth factor I (IGF1) and IGF binding protein levels in swine. Domestic Animal Endocrinology 4:23-31.

Burrin, D. G.; Wester, T. J.; Davis, T. A.; Amick, S. and Heath, J. P. 1996. Orally administered IGF-I increases intestinal mucosal growth in formula-fed neonatal pigs. American Journal of Physiology 270:1085-1091.

Cameron, N. D.; McCullough, E.; Troup, K. and Penman, J. C. 2003. Serum insulin-like growth factor-1 concentrations in pigs devergently selected for daily food intake or lean growth rate. Journal of Animal Breeding and Genetics 120:228-236.

Chen, K.; Okuma, T.; Okamura, K.; Tabira, Y.; Kaneco, H. and Miyauchi, Y. 1995. Insulin like growth factor-1 prevents gut atrophy and maintains intestinal integrity in septic rats. Journal of Parenteral and Enteral Nutrition 19:119-124.

Cho, J. H.; Chen, Y. J.; Min, B. J.; Kim, H. J.; Kwon, O. S.; Shon, K. S.; Kim, I. H.; Kim, S. J. and Asamer, A. 2006. Effects of essential oils supplementation on growth performance, IgG concentration and fecal noxious gas concentration of weaned pigs. AsianAustralasian Journal of Animal Sciences 19:80-85. 
Cho, J. H.; Zhang, S. and Kim, I. H. 2012. Effects of anti-diarrhoeal herbs on growth performance, nutrient digestibility and meat quality in pigs. Asian-Australasian Journal of Animal Sciences 25:1595-1604.

Choi, C. S.; Kim, J. S.; Lee, C. W.; Park, J. S. and Hong, E. K. 2002. Effect of plant extract (YGF) on inducing IGF-I secretion. Korean Society for Biotechnology and Bioengineering Journal 17:203-206.

Claustres, M.; Chatelian, P. and Sultan, C. 1987. Insulin like growth factor 1 stimulates human erythroid colony formation in vitro. The Journal of Clinical Endocrinology and Metabolism $65: 78-82$

Eigenmann, J. E.; Patterson, D. F. and Froesch, E. R. 1984. Body size parallels insulin-like growth factor1 levels but not growth hormone secretory capacity. ACTA Endocrinol-cop 106:448-453.

Hinton, P. S.; Peterson, C. A.; Dahly, E. M. and Ney, D. M. 1997. IGF-I alters lymphocyte survival and regeneration in thymus and spleen after dexamethasone treatment. American Journal of Physiology 274:912-920.

Huang, A.; Yoo, J. S.; Kim, H. J.; Wang, Y.; Chen, Y. J.; Cho, J. H. and Kim, I. H. 2010. Effects of dietary supplementation with blended essential oils on growth performance, nutrient digestibility, blood profiles and fecal characteristics in weanling pigs. Asian Australasian Journal of Animal Sciences 23:607-613.

Kim, J. S. 2006. Compositions for inducing secretion of insulin-like growth factor-1. US Patent; No. US 6,984, 405 BI.

Kim J. S.; Park J. H.; Cho H. S.; Park J. S. and Hong E. K. 2002. Effects of YGF251 on secretion of IGF-I in human blood. Korean Journal of Biotechnology and Bioengineering 17:403-408.

Klindt, J.; Yen, J. T.; Buonomo, F. C.; Roberts, A. J. and Wise T. 1998. Growth, body composition, and endocrine responses to chronic administration of insulin-like growth factor 1 and (or) porcine hormone in pigs. Journal of Animal Science 76:2368-2381.

Kurtz, A.; Jelkmann, W. and Bauer, C. 1982. A new candidate for the regulation of erythropoiesis: insulin like growth factor 1. FEBS Letters 149:105-108.

Lamberson, W. R.; Safranski, T. J.; Bates, R. O.; Keisler, D. H. and Matteri, R. L. 1995. Relationships of serum insulin-like growth factor I concentrations to growth, composition, and reproductive traits of swine. Journal of Animal Science 73:3241-3245.

Lee, C. Y.; Baik, K. H.; Park, B. C. and Park, H. C. 2005. Relationships of plasma insulin-like growth factor (IGF)-I and IGF-II concentrations to growth in purebred Landrace and Yorkshire female pigs. Livestock Production Science 95:163-169.

Lee, C. Y.; Lee, H. P.; Jeong, J. H.; Baik, K. H.; Jin, S. K.; Lee, J. H. and Sohn, S. H. 2002. Effects of restricted feeding, low-energy diet, and implantation of trenbolone acetate plus estradiol on growth, carcass traits, and circulating concentrations of insulinlike growth factor (IGF)-I and IGF-binding protein-3 in finishing barrows. Journal of Animal Science 80:84-93.

Lemmey, A. B.; Ballard, F. J.; Martin, A. A.; Tomas, F. M.; Howarth, G. S. and Read, L.C. 1994. Treatment with IGF-I peptides improves function of the remnant gut following small bowel resection in rats. Growth Factors 10:243-252.

Liu, G. M.; Wei, Y.; Wang, Z. S.; Wu, D.; Zhou, A. G. and Liu, G. L. 2008. Effects of herbal extract supplementation on growth performance and insulin-like growth factor (IGF)-1 system in finishing pigs. Journal of Animal and Feed Sciences 17:538-547.
Liu, J. L. and LeRoith, D. 1999. Insulin-like growth factor I is essential for postnatal growth in response to growth hormone. Endocrinology 140:5178-5184.

Morovat, A.; Burton, K. A. and Daucey, M. J. 1994. Short-term regulation of plasma IGF-I concentration by food intake in young pigs. Hormone and Metabolic Research 26:265-269.

NRC - National Research Council. 1998. Nutrient requirements of swine. National Academy Press, Washington, DC, USA.

Owens, P. C.; Campbell, R. G.; Francis, G. L. and Quinn, K. J. 1994. Growth hormone, gender and insulin-like growth factors: Relationship to growth performance in pigs. Journal of Animal Science 72(Suppl. 1):253.

Owens, P. C.; Gatford, K. L.; Walton, P. E.; Morley, W. and Campbell, R. G. 1999. The relationship between endogenous insulin-like growth factors and growth in pigs. Journal of Animal Science 77:2098-2103

Ra, J. C.; Kim, J. H.; Lee, J. E.; Park, H. G.; Kim, S. H. and Kang, K. S. 2003. Studies on the development on rise with plant extracts for enhancing growth rate. (VC Speech) Korean Journal of Oriental Physiology and Pathology 17:815-818.

Scanes, C. G.; Lazarus, D.; Bowen, S.; Buonomo, F. C. and Gilbreath, R. L. 1987. Postnatal changes in circulating concentrations of growth hormone, somatomedin $\mathrm{C}$ and thyroid hormones in pigs. Domestic Animal Endocrinology 4:253-257.

Stuart, C. A.; Meehan, R. T.; Neale, L. S.; Clintrol, N. M. and Furlanetto, R. W. 1991. Insulin like growth factor-1 binds selectively to human peripheral blood monocytes and B-lymphocytes. Journal of Clinical Endocrinology and Metabolism 72:1117-1122.

Suzuki, K.; Nakagawa, M.; Katoh, K.; Kadowaki, H.; Shibata, T.; Uchida H.; Obara, Y. and Nishida, A. 2004. Genetic correlation between serum insulin-like growth factor-1 concentration and performance and meat quality traits in Duroc pigs. Journal of Animal Science 82:994-999.

Yan, L.; Meng, Q. W. and Kim, I. H. 2011a. Effect of an herb extract mixture on growth performance, nutrient digestibility, blood characteristics and fecal noxious gas content in growing pigs. Livestock Science 141:143-147.

Yan, L.; Meng, Q. W. and Kim, I. H. 2011b. The effects of dietary Houttuynia cordata and Taraxacum officinale extract powder on growth performance, nutrient digestibility, blood characteristics and meat quality in finishing pigs. Livestock Science 141:188-193.

Yan, L.; Meng, Q. W. and Kim, I. H. 2012. Effect of an herb extract mixture on growth performance, nutrient digestibility, blood characteristics and fecal microbial shedding in weanling pigs. Livestock Science 145:189-195.

Yan, L.; Wang, J. P.; Kim, H. J.; Meng, Q. W.; Ao, X.; Hong, S. M. and Kim, I. H. 2010. Influence of essential oil supplementation and diets with different nutrient densities on growth performance, nutrient digestibility, blood characteristic, meat quality and fecal noxious gas content in grower-finishing pigs. Livestock Science 128:115-122.

Zahn, J. A.; Hatfield, J. L.; Do, Y. S, Dispirito, A. A.; Laird, D. A. and Pfeiffer, R. L. 1997. Characterization of volatile organic emission and wastes from a swine production facility. Journal of Environmental Quality 26:1687-1696.

Zhou, T. X.; Zhang, Z. F. and Kim, I. H. 2013. Effects of dietary coptis chinensis herb extract on growth performance, nutrient digestibility, blood characteristics and meat quality in growing-finishing pigs. Asian-Australasian Journal of Animal Sciences 26:108-115. 